\title{
Trenger vi overjeget?
}

«Overjeg» er et sentralt begrep i psykoanalysen og nyttig i vår forståelse av psykopatologi. Den ubevisste delen av overjeget er årsak til mye psykisk lidelse. Å mildne et strengt og straffende overjeg er et av de viktigste målene for psykoterapi.

En morgen jeg hørte på Mytekalenderen på NRK P2 startet den sånn: «Det var noe ganske besynderlig ved det jeg følte, noe ubeskrivelig nytt og, på grunn av dets nyhet, usigelig deilig. Jeg følte meg yngre, lettere, lykkeligere, jeg merket hos meg selv en berusende og hensynsløs likegladhet, en strøm av uklare, sanselige forestillinger som fosset gjennom min fantasi, jeget og overjeget $(2,3)$. Disse modellene supplerer hverandre. F.eks. fant Freud at ikke bare id, men også deler av jeget og overjeget kan være ubevisst. Det er spesielt de ubevisste delene av overjeget, som handler om dyp og uerkjent skam, skyldfølelse og straffebehov, som skaper psykiske problemer.

Vår håndtering av ubevisst skyld vil

\section{«Overjeget er lett oppløselig i alkohol»}

en følelse av å være løst fra alle plikters bånd, en uanet men langt fra uskyldig sjelelig frihet.»

Jeg rakk akkurat å tenke: $\AA$, det lød deilig, før Terje Nordby fortalte at sitatet stammet fra Dr. Jekyll og Mr. Hyde av R.L. Stevenson (1850-94). Dr. Jekyll beskriver hvordan han opplever virkningen av sin medisin - hvordan han blir Mr. Hyde, en mann blottet for moral og skrupler (1). Allikevel: Umiddelbart ga dette meg en opplevelse av hvordan det kjennes når trykket fra overjeget letner, litt på samme måte som ved alkoholrus. Det er sagt at overjeget er lett oppløselig i alkohol. Overjeget ble beskrevet av Sigmund Freud (1856-1939) som en instans i psyken, atskilt fra jeget, som fungerer som en slags indre foreldrestemmer. Det vil si at det har skjedd en internalisering av foreldrenes idealer, forbud og krav. Overjeget består av en idealdel, med bevisste og ubevisste forestillinger om moral, rett og galt, godt og ondt, og en utøvende del, en vokter, som stenger for driftsutfoldelse, sensurerer, hemmer, tilpasser og skaper nevrotiske symptomer (2). Overjeget er en instans som er nødvendig for kulturens opprettholdelse og mellommenneskelig samkvem - i det hele tatt noe som særpreger oss som mennesker og som skiller oss fra dyrene. Den kan også sies å være delaktig i de fleste psykiske lidelser.

\section{Ubevisst skyld}

Freud postulerte to modeller for psyken: Først den topografiske - med tredelingen bevisst, førbevisst, ubevisst - senere strukturmodellen, med tredelingen driftene (id), variere, avhengig av konstitusjon og de underliggende psykiske traumenes art og omfang. Freud beskrev en variant som «de som går til grunne ved suksess» (4). Freud henviste til Rebekka West i Ibsens Rosmersholm som eksempel på dette. Etter lang kamp oppnår hun det hun ønsker, men som hennes ubevisste skyldfølelse nekter henne. Et strengt og straffende overjeg, formet av en traumatisk oppvekst, driver henne til å kaste seg i fossen i stedet for å ta imot lykken. Et beslektet fenomen kan oppstå i terapi, der man kan møte pasienter som ikke tåler å få det bra, en såkalt negativ terapeutisk reaksjon. Overjeget motsetter seg bedring (2).

Dr. Jekyll og Mr. Hyde blir ofte brukt som metafor for det som i ICD-10-språk benevnes multippel personlighet (F44.81). Det vesentlige kjennetegnet er en tydelig sameksistens av to eller flere separate personligheter i samme individ, men der bare én er til stede om gangen. Dette kan anses som en annen måte å leve med et uhåndterlig overjeg på - ikke ved å fortrenge det, slik Rebekka West gjorde, men ved å spalte det av. Dr. Jekyll forblir den respektable legen som, fritatt fra overjegets trykk, lever ut sine forbudte driftsønsker som Mr. Hyde.

\section{Et nyttig overjeg}

Overjeget er etter min mening et nyttig psykologisk konstrukt som vi trenger for vår forståelse av psykopatologi. I behandlingshverdagen kan spørsmålet om vi trenger overjeget besvares slik: Ja, vi trenger et medgjørlig, romslig og mest mulig bevisst overjeg, som kan veilede oss mht. hva som er rett og galt, og som til og med kan si: «OK, nå dummet du deg kanskje ut, men det er ikke så farlig; du er bra nok likevel». Det vi ikke trenger, fordi det virker hemmende og destruktivt, er det ubevisste, strenge, fordømmende overjeget, som hvisker: «Skam deg. Du er skyldig. Du er ikke verdt noe. Du fortjener ikke å lykkes med noe her i livet.»

Et viktig mål for psykoterapi er å få belyst disse ubevisste og førbevisste tankene og følelsene; se på dem, kna dem, forsøke å rekonstruere bakgrunnen for dem, modifisere dem og slik få et mer romslig og tolerant overjeg. Til og med dissosiative tilstander av Jekyll/Hyde-typen vil kunne være tilgjengelige for behandling (5).

Mange som går i terapi og merker at overjeget begynner å lette på trykket, uttrykker engstelse for at de kanskje utvikler seg til psykopater. Men man mister ikke overjeget sitt i terapi, i beste fall bare sin «indre sabotør» (6).

\section{Espen Bjerke}

espbje@so-hf.no

Sykehuset Østfold

Divisjon for psykisk helsevern

DPS Moss

Postboks 370

1502 Moss

Oppgitte interessekonflikter: Ingen

\section{Litteratur}

1. Stevenson RL. Dr. Jekyll og Mr. Hyde. Oslo: Den norske Bokklubben, 1985: 156

2. Strachey J, red. The ego and the id. Bd. 19. The standard edition of the complete psychological works of Sigmund Freud. London: Hogarth, 1961

3. Strachey J, red. The interpretation of dreams. Bd. 2. The standard edition of the complete psychological works of Sigmund Freud. London: Hogarth, 1955

4. Strachey J, red. Some character-types met with in psycho-analytic work. Bd. 14. The standard edition of the complete psychological works of Sigmund Freud. London: Hogarth, 1957

5. Gullestad S. Who is 'who' in dissociation? A plea for psychodynamics in a time of trauma. Int J Psychoanal 2005: 86: 639-56.

6. Fairbairn WR. Psychoanalytic studies of the personality. London: Routledge \& Kegan Paul, 1952.

Manuskriptet ble mottatt 14.8. 2008 og godkjent 19.11. 2008. Medisinsk redaktør Åslaug Helland. 